\title{
TNFRSF10C Gene
}

National Cancer Institute

\section{Source}

National Cancer Institute. TNFRSF10C Gene. NCI Thesaurus. Code C104514.

This gene is involved in both lig and binding and the negative regulation of apoptotic signaling. 